\title{
Synthesis and characterization of calcium phosphorylated inulin complex as a new source of enriched calcium supplement with prebiotic effect in food
}

\author{
Lingyun WEI ${ }^{1 *}$, Wenzhu YANG ${ }^{2}$, Jianhua WANG ${ }^{3}$, Quanhua TIAN ${ }^{1}$, Zhixiong $\mathrm{HE}^{2}$
}

\begin{abstract}
Bioavailability of calcium in food is not high. Calcium ions can react with the organic acids such as oxalic acid and phytic acid in the food to form insoluble salt. Calcium phosphorylated inulin (CaPInu) was developed as a new potential functional food. Inulin was chemically modified by importing charged group using esterification with phosphate mixture in order to chelate calcium. Two equivalence points of the introduced phosphate groups were estimated to be around 3.85 and 8.76 by potentiometric titration. The structural characterization indicated that $\mathrm{C}_{6}-\mathrm{OH}$ in the chemical structure of phosphorylated inulin was located in the outside of the sugar ring and its steric hindrance was relatively small and esterification was performed with phosphate easily. CaPInu could stimulate the growth of Bifidobacteria and decrase $\mathrm{pH}$ in vitro fermentation. Low $\mathrm{pH}$ in colon is benefit to the dissolution of calcium. Mice fed CaPInu diet had a higher serum calcium and femur weight compared with the control diet.
\end{abstract}

Keywords: calcium phosphorylated inulin; degree of substitution; chelate; Bifidobacteria; colon.

Practical Application: CaPInu is a potential source of enriched calcium supplement, and has beneficial effects on intestinal health.

\section{Introduction}

Inulin is a non-branched polydisperse fructan that mainly consists of $\beta(2 \rightarrow 1)$ linked fructose units with a glucose unit at the reducing end (Morros et al., 2011; Lingyun et al., 2007). It belongs to a class of fibers known as non-digestible oligosaccharide that improve or maintain colon health as a prebiotic (Dewulf et al., 2013; Miremadi \& Shah, 2012; Butts et al., 2016). Over the last few decades, inulin has been modified by various methods to achieve functionalities suitable for various applications such as carboxymethylinulin, inulin-D- $\alpha$-tocopherol succinate, p(inulin) microgel (Verraest et al., 1995; Mandracchia et al., 2014; Sahiner \& Sagbas, 2014). Inulin was acylated with acetic anhydride, propionic anhydride, or butyric anhydride. Gallic acid (GA) was encapsulated with native (NIn), cross-linked (CIn) and acetylated inulin (AIn). Gallic acid release profile data in yogurt for GA-NIn, GA-CIn and GA-AIn were fitted to Peppas and Higuchi models (García et al., 2015). Acylation of inulin was beneficial for traveling through the upper gastrointestinal tract intact, delivering high concentrations of short chain fatty acid (SCFA) to more distal regions of the colon and remained bifidogenicity (Hartzell et al., 2013a). Inulin was esterified with 5 -formylaminosalicylic acid (5-fASA). During in vitro digestion and fermentation of 5-fASA-inulin, conjugation of inulin with 5-fASA supported SCFA and especially butyrate-producing bacteria through fermentation in the distal colon (Hartzell et al., 2013b).

Bioavailability of calcium in food is not high. Calcium ions can react with the organic acids such as oxalic acid and phytic acid to form insoluble salt (Weaver et al., 1987; Dendougui \& Schwedt, 2004). Inulin was chemically modified with a charged group in order to chelate calcium. Inulin can promote the growth and lactic acid production of Bifidobacteria (Roberfroid, 2007). Lactic acid can facilitate the dissolution of calcium in colon (Coudray et al., 2005; Abrams et al., 2005; Griffin et al., 2003). A 12-month study with 100 adolescents ingesting $8 \mathrm{~g} /$ day shortand long-chain inulin fructans showed a significant increase in calcium absorption that led to greater bone mineral density (Slavin, 2013; Scholz-Ahrens et al., 2002). The aim of this work was the synthesis and the function of the derivatives based on inulin. The inulin derivatives were able to chelate calcium. Calcium ions were released out to be absorbed after the inulin derivatives were fermented by bacteria in colon (Jedrzejczak-Krzepkowska et al., 2011). It can effectively avoid that calcium ions directly reacted with the organic acids in food to form insoluble salt. The inulin derivatives will be a new source of enriched calcium supplement with prebiotic effect in food (Legette et al., 2012).

\section{Materials and methods}

\subsection{Materials}

The purified inulin, Frutafit $\mathrm{HD}$, with an average degree of polymerization of about 8 , was supplied by Sensus Corporate (Roosendaal, the Netherlands). Sodium dihydrogen phosphate dihydrate and disodium hydrogen phosphate anhydrous were obtained from Sigma-Aldrich (Steinheim, Germany). All other chemicals used were of laboratory grade. 


\subsection{Synthesis of phosphorylated inulin (PInu)}

Phosphorylation of inulin was performed by reacting inulin with a mixture of sodium dihydrogen phosphate dihydrate and disodium hydrogen phosphate anhydrous consisting of molar ratio $\left(\mathrm{NaH}_{2} \mathrm{PO}_{4} \cdot 2 \mathrm{H}_{2} \mathrm{O} / \mathrm{Na}_{2} \mathrm{HPO}_{4}\right)=0.6393: 1$ to keep the medium $\mathrm{pH}$ at 7. Different amounts of phosphate mixture were used in order to obtain phosphorylated inulin with different degrees of substitution of phosphate groups (DSp) (Sitohy et al., 2000). Prior to phosphorylation, inulin was dissolved in equal weight water at $90{ }^{\circ} \mathrm{C}$. Accurate amounts of $\mathrm{NaH}_{2} \mathrm{PO}_{4} \cdot 2 \mathrm{H}_{2} \mathrm{O}$ and $\mathrm{Na}_{2} \mathrm{HPO}_{4}$ were calculated to prepare different molar ratios of phosphating agent to inulin, i.e., $0.3: 1,0.4: 1,0.5: 1,0.6: 1$, $0.7: 1,0.8: 1,0.9: 1,1: 1,1.1: 1$. Phosphate mixture was added to the inulin solution and the resulting mixture was stirred for 2 hour at $80^{\circ} \mathrm{C}$. After cooling down to room temperature the reaction product was precipitated and stirred in methanol for 30 min to remove non-reacted phosphate and degradation products of inulin by vacuum filtration. The filtered product was dehydrated by washing with absolute ethanol, then lyophilized and grinded to obtain white powder. The reaction scheme was shown in Figure 1.

\subsection{Colorimetric determination of the phosphorus content and calculation of the degree of substitution}

The phosphorus content of phosphorylated inulin was determined using the vanadomolybdophosphoric acid method (Noguchi et al., 2017; Wongsagonsup et al., 2005). The degree of substitution of phosphate groups (DSp) was calculated according to the following Equation 1 (Passauer et al., 2010).

$$
D S p=\frac{162 P}{3100-103 P}
$$

With $\mathrm{P}$ being the colorimetric determined percentage of phosphorus content of the phosphorylated inulin, 162 the molar mass of the anhydrofructose unit, 3100 the atomic weight of phosphorus multiplied by 100 and 103 the molar mass of the phosphate substituent $\left(-\mathrm{NaHPO}_{3}\right)$.

\subsection{Titration curve for phosphorylated inulin}

$20 \mathrm{~mL}$ of $1 \%$ phosphorylated inulin solution were pipetted into a $100 \mathrm{~mL}$ beaker. The $\mathrm{pH}$ probe was inserted. The magnetic stirrer was turned on and the stirring ratio was adjusted to a moderate speed without splashing. $0.20 \mathrm{~mL}$ of $1 \mathrm{M} \mathrm{NaOH}$ were added at a time. The total volume of $\mathrm{NaOH}$ and $\mathrm{pH}$ value should be written down. Continue until the $\mathrm{pH}$ had reached approximately 12 . The $\mathrm{pH}$ value versus $\mathrm{mL} \mathrm{NaOH}$ was graphed to display the titration curve for phosphorylated inulin (Nishi et al., 1986).

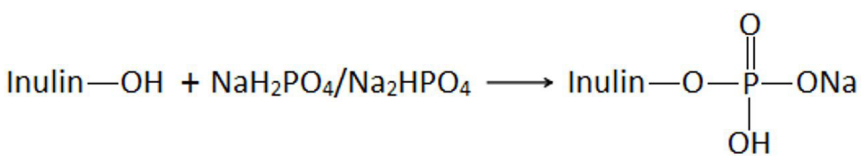

Figure 1. Reaction scheme for the preparation of phosphorylated inulin.

\subsection{Chelating ability of phosphorylated inulin for calcium}

$30 \mathrm{~mL}$ of the $0.04 \mathrm{M} \mathrm{CaCl}_{2}$ solution were pipetted into a $250 \mathrm{~mL}$ Erlenmeyer flask. 2 drops of Calmagite indicator and $5 \mathrm{~mL}$ of $\mathrm{pH} 10$ buffer were added. The initial color should be in wine red colour. The solution was titrated with the $0.04 \mathrm{M}$ phosphorylated inulin with continuous swirling until the wine red colour turned into a blue endpoint. The titration was conducted in triplicate. The chelating ability of sample for calcium was calculated according to the relation (Equation 2):

$X=\frac{0.04 \times 30 \times 40}{0.04 \times V \times(162+103 \times D S p)} \times 1000$

With $\mathrm{V}$ being the titration determined volume of the phosphorylated inulin, 162 the molar mass of the anhydrofructose unit, 40 the atomic weight of calcium and 103 the molar mass of the phosphate substituent $\left(-\mathrm{NaHPO}_{3}\right)$. Chelating ability of EDTA and citric acid was tested at the same time (Yu et al., 2006).

\subsection{FTIR spectroscopy}

The powder of inulin, phosphorylated inulin and CaPInu were examined by Fourier transform infrared (FTIR) spectroscopy, on Nicolet Avatar 370 using a KBr pellet.

\subsection{NMR spectroscopy}

The ${ }^{1} \mathrm{H}$ NMR spectra and ${ }^{13} \mathrm{C}$ NMR spectra of phosphorylated inulin were recorded with a JEOL JMNGSX-400 MHz spectrometer in $\mathrm{D}_{2} \mathrm{O}$. For those measurements, $10 \mathrm{mg}$ of the sample was introduced into a NMR test tube, to which $\mathrm{D}_{2} \mathrm{O}$ was added, and finally the tube was kept at $70{ }^{\circ} \mathrm{C}$ to dissolve the sample in solution.

\subsection{Growth of bifidobacteria in various carbohydrates}

Bifidobacterium animalis CICC 6165 was obtained from China Center of Industrial Culture Collection. The blank medium contained (in grams per liter) peptone (5), tryptone (5), yeast extract (10), L-Cys. $\mathrm{HCl}(0.5)$, magnesium sulfate (0.02), calcium chloride (0.008) and pH7.0 (Palumbo et al., 1996). The carbohydrates such as glucose, inulin, carboxymethylcellulose (CMC), phosphorylated inulin (PInu), CaPInu were added at $10 \mathrm{~g} / \mathrm{L}$ to the blank medium respectively. The liquid media were sterilized at $121^{\circ} \mathrm{C}$ for $20 \mathrm{~min}$. The Bifidobacterium animalis suspension was transferred into $50 \mathrm{~mL}$ anaerobic culture bottle containing of $40 \mathrm{~mL}$ liquid medium. After $48 \mathrm{~h}$ of anaeorbic incubation at $37^{\circ} \mathrm{C}$, the $\mathrm{pH}$ of culture medium was determined using $\mathrm{pH}$ meter. Anaerobic conditions were ensured using AnaeroGen (Oxoid, Basingstoke, UK). Bifidobacterium animalis populations were counted by pour-plating $1 \mathrm{~mL}$ of each dilution in modified PTYG (peptone-tryptone-yeast extract-glucose) agar medium. Colony forming units (CFU) were enumerated in plates containing 30-300 colonies, and cell concentration was expressed as log CFU/g (James, 2014). 


\subsection{Animal experiment}

Thirty male KM mice were obtained from the Center for Animal Experiment, Wuhan University at age of 3 weeks (initial body weight, 11.1-12.7 g), and were randomly assigned into one of 3 treatments ( 10 mice/treatment). The mice were allowed free access to pellet diets and distilled deionized water during the experiment. The diet composition was presented in Table 1. The level of Ca in control diet was $1.5 \mathrm{~g} / \mathrm{kg}$ dry matter (DM) basis. The levels of $\mathrm{Ca}$ in calcium citrate diet and CaPInu diet were $5 \mathrm{~g} / \mathrm{kg}$. The ambient temperature during the study was maintained between $21^{\circ} \mathrm{C}$ and $23^{\circ} \mathrm{C}$, and the mice were exposed to a 12 -h light, 12 -h dark cycle. Animal studies were performed in compliance with relevant regulations relating to the guidelines of animal experiments and all procedures were approved by the local ethics committee of Wuhan University (No.: 2015102702). The experiment lasted for 31 days in total. The mice were sacrificed after the dark period (between 08:00 and 10:00 AM) with 12 hours of fasting. The animals were weighed before and after the experiment and their food consumption was measured daily. Calcium and phosphate concentrations in the serum were determined (Bogden et al., 2008). The femurs and tibias were isolated, cleaned of soft tissues. The bones were then dried to constant weight and measured, weighed (Broulík \& Broulíková, 2007).

\subsection{Statistical analyses}

The determinations of DSp of phosphorylated inulin, $\mathrm{pH}$ in titration, $\log \mathrm{CFU} / \mathrm{g}$ and $\mathrm{pH}$ values for Bifidobacterium animalis growth were done in three repetitions. The results were expressed as mean \pm SD (standard deviation). Statistical analyses were performed with SPSS 16.0 software for windows (SPSS Inc., Chicago, IL, USA). A one-way ANOVA was used for comparisons of the single variables to identify significant differences. A Tukey's test was conducted when a significant difference was found $(\mathrm{p}<0.05)$.

\section{Results and discussion}

\subsection{Degree of substitution of phosphorylated inulin}

The colorimetric determined degree of substitution of phosphorylated inulin ranged between 0.047 and 0.215 (Figure 2), corresponding to different amounts of phosphate mixture which had been used for inulin phosphorylation. The DSp increased rapidly with the molar ratio (phosphate/inulin) extended from 0.4 to 0.8 in the chemical reaction process, but increased slightly then leveled off from 0.8 to 1.1 . The results suggested that the molar ratio (phosphate/inulin) 0.9 in the chemical reaction process was high DSp (0.209) yield and feasible. Reports on the phosphorylation of inulin have been hardly seen so far. Starch was phosphorylated to different degrees of substitution using monosodium and disodium hydrogen orthophosphate at $160^{\circ} \mathrm{C}$ under vacuum. The DSp of phosphorylated starch could reach 0.33 (Sitohy et al., 2000). The reaction temperature at $160^{\circ} \mathrm{C}$ was so high for inulin because the phosphorylation of oligosaccharides had more side reactions than starch. This synthetic route of phosphrylated inulin had a mild reaction condition and was easy to control.

\subsection{Titration curve}

Titration curve for phosphorylated inulin (DSp $=0.209)$ was shown in Figure 3. Potentiometric titration was performed slowly with $3 \mathrm{~h}$ to obtain accurate titration curve. The titration curve ( $\mathrm{pH}$ vs vol. of titrant) with $1 \mathrm{M} \mathrm{NaOH}$ was determined

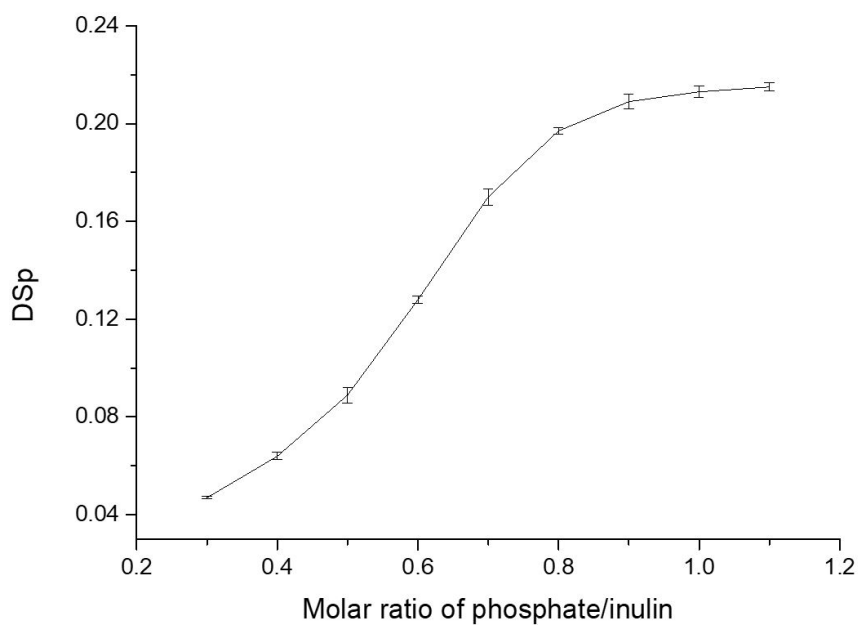

Figure 2. Effect of molar ratio (phosphate/inulin) on the DSp of phosphorylated inulin. Each value was expressed as mean $\pm \operatorname{SD}(n=3)$.

Table 1. Diet composition (g/kg DM) during the experiment.

\begin{tabular}{lccc}
\hline & Control diet & Calcium citrate diet & CaPInu diet \\
\hline Corn starch & 320 & 320 & 320 \\
Sucrose & 296.25 & 281.72 & 214.85 \\
Casein & 230 & 230 & 230 \\
Corn oil & 50 & 50 & 50 \\
Cellulose & 50 & 50 & 50 \\
Ca-free Mineral mix (AIN-93G) & 35 & 35 & 35 \\
Vitamin mix (AIN-93G) & 10 & 10 & 10 \\
Dl-Methionine & 3 & 3 & 3 \\
Choline bi-tartrate & 2 & 2 & 2 \\
CaCO & 3.75 & 3.75 & 3.75 \\
Calcium citrate & 0 & 14.53 & 0 \\
CaPInu & 0 & 0 & 81.40 \\
\hline Ca-fris & \\
\hline
\end{tabular}

Ca-free Mineral mix (AIN-93G) ensures the following mineral levels in the diets (per kg dry matter): P, 1.56 g; K, 3.6 g; S, 0.3 g; Mg, 0.5 g; Na, 1.0 g; Cl, 1.6 g; Cu, 6.0 mg; I, 0.2 mg; Fe,

$37 \mathrm{mg}$; Mn, $10.5 \mathrm{mg}$; Se, $0.2 \mathrm{mg}$; Zn, $30 \mathrm{mg}$; CaPInu = Calcium phosphorylated inulin. 


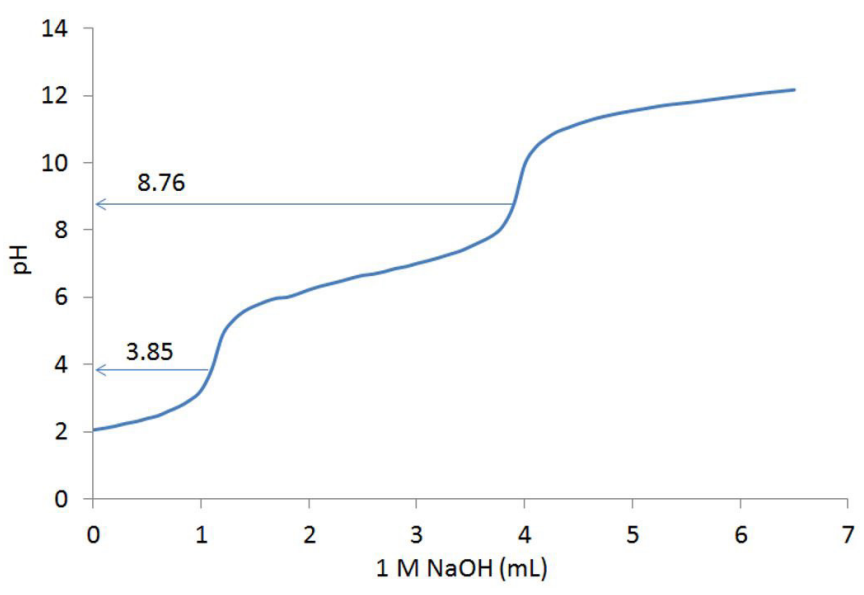

Figure 3. Schematic $\mathrm{pH}$ titration curve of $1 \%$ phosphorylated inulin with $1 \mathrm{M} \mathrm{NaOH}$.

using a $\mathrm{pH}$ meter, with the inflection points being used as the equivalence points. The first equivalence point was approximately 3.85. The second equivalence point was approximately 8.76 . Two equivalence points were clearly indicated in the titration curve for the phosphate group of phosphorylated inulin. The phosphorylated inulin was found to give fairly broad titration curves and maintain a dissolved state over a wide $\mathrm{pH}$ range for its buffer capacity probably owing to its phosphate group. At the same time, the solubility of phosphorylated inulin in water could be increased by adding the base. The solubility of phosphorylated inulin in the acidic environment of the stomach can be decreased so that the speed of its hydrolysis reaction is slow. With $\mathrm{pH}$ increasing of the intestine, the solubility and digestibility of phosphorylated inulin will be accelerated.

\subsection{Chelating ability of phosphorylated inulin for calcium}

Inulin was chemically modified by esterification with phosphate mixture, which can conjugated with calcium. The chelating ability of phosphorylated inulin (DSp $=0.209)$ for calcium was $103.6 \pm 1.1 \mathrm{mg} / \mathrm{g}$. In this assay method, the chelating ability of EDTA for calcium was $269.2 \pm 0.7 \mathrm{mg} / \mathrm{g}$ and citric acid was $90.3 \pm 0.2 \mathrm{mg} / \mathrm{g}$. The chelating ability of EDTA was significant stronger $(p<0.01)$ than that of phosphorylated inulin and citric acid. EDTA can be used to remove unwanted minerals and metals from the blood. The chelating ability of phosphorylated inulin for calcium was higher $(\mathrm{p}<0.01)$ than that of citric acid. Phosphorylated inulin was stable in the stomach, small intestine and its phosphate groups could bind calcium strongly.

\subsection{Characterization of phosphorylated inulin by FTIR}

The purified samples of inulin, phosphorylated inulin and CaPInu were characterized by the functional groups using FTIR technique. The IR spectra were presented in Figure 4. The inulin exhibited a very broad band in the region $3500-3200 \mathrm{~cm}^{-1}$, centered at about $3350 \mathrm{~cm}^{-1}$ due to various $\mathrm{O}-\mathrm{H}$ stretching in sugar rings (Abou-Arab et al., 2011). The absorption peak at $2933 \mathrm{~cm}^{-1}$ represented the $\mathrm{C}-\mathrm{H}$ stretching in sugar rings (Grube, 2002). The weak peak at $1639 \mathrm{~cm}^{-1}$ was attributed

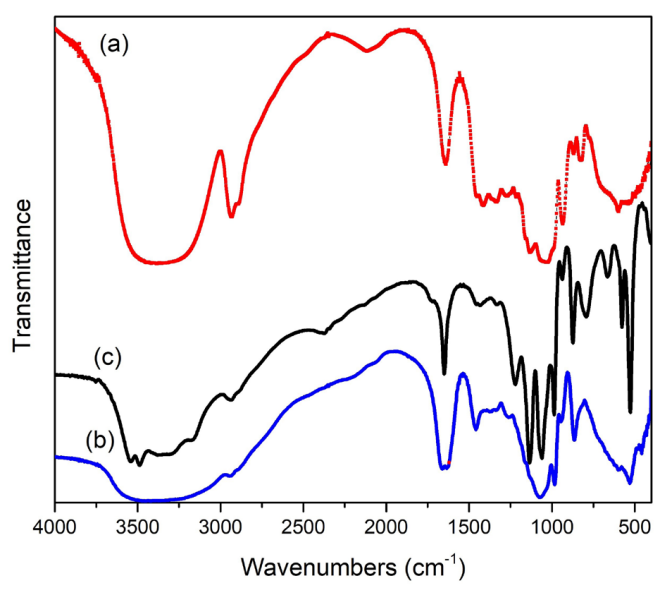

Figure 4. FTIR spectra of (a) inulin, (b) phosphorylated inulin and (c) calcium phosphorylated inulin (CaPInu).

to $\mathrm{C}=\mathrm{O}$ stretching of fructose. The strong peak at $1032 \mathrm{~cm}^{-1}$ was attributed to $\mathrm{C}-\mathrm{O}$ stretching of primary alcohol in sugar rings. Phosphorylation of inulin led to an emerging peak at $1662 \mathrm{~cm}^{-1}$, which was attributed to the $\mathrm{P}=\mathrm{O}$ asymmetric stretching from phosphates. An increase in the absorbance of the peak at $1074 \mathrm{~cm}^{-1}$ was also observed, and was assigned to the C-O-P stretching in phosphate esters, overlapping the $\mathrm{C}-\mathrm{O}$ stretching vibrations in inulin ether groups, in accordance to the substitution of a hydroxyl group by a phosphate one (Jayakumar et al., 2008). Furthermore, the enlarged band between 3600 and $3100 \mathrm{~cm}^{-1}$ showed that the peaks of $\mathrm{O}-\mathrm{H}$ stretching in sugar overlapped those in $\mathrm{P}-\mathrm{OH}$ group. The absorptions due to $\mathrm{P}-\mathrm{O}$ bond in phosphate group at $1000-1250 \mathrm{~cm}^{-1}$ changed remarkably by the binding of $\mathrm{Ca}^{2+}$ ion (Nishi et al., 1987). The presence of sharp peak at $1236 \mathrm{~cm}^{-1}$ and the clear peak at $862 \mathrm{~cm}^{-1}$ were attributed to formed ionic bond $(\mathrm{Ca}-\mathrm{O})$ into this derivative (Shnawa, 2011). The FTIR spectra confirmed that the phosphorylation occurred in inulin and the phosphate group worked cooperatively for the calcium-binding.

\section{$3.5{ }^{1} \mathrm{H} N M R$ and ${ }^{13} \mathrm{C}$ NMR spectra of phosphorylated inulin}

The ${ }^{1} \mathrm{H}$-NMR spectra of phosphorylated inulin were shown in Figure $5 \mathrm{~A}$. The ${ }^{1} \mathrm{H}$ of $\mathrm{H}_{2} \mathrm{O}$ had a high peak at $4.79 \mathrm{ppm}$ indicating the powder of phosphorylated inulin were easy to absorb moisture. The resonance signals in the range between 4.26 and $3.60 \mathrm{ppm}$ were caused by hydrogen atoms in the sugar rings of inulin (Wu \& Lee, 2000). In contrast, the ${ }^{1} \mathrm{H}$ of $\mathrm{P}-\mathrm{OH}$ appeared at a chemical shift of $1.15 \mathrm{ppm}$. The ${ }^{1} \mathrm{H}$ NMR spectra confirmed the successful incorporation of the phosphate group into the inulin.

The ${ }^{13} \mathrm{C}$ NMR spectra of phosphorylated inulin was given in Figure 5B. The spectra-showed that all the signals from each carbon were well separated from each other, and the carbons attached to the substituted hydroxyl group were clearly distinguished from the non-substituted one (Jayakumar et al., 2009). The C-2 resonance $(\delta=103.16 \mathrm{ppm})$ was attributed anomeric carbons and indicated the presence of $\beta$-fructofuranose (van Hijum et al., 2001). The peaks at $57.46,62.16,69.26,74.34$ and $81.10 \mathrm{ppm}$ 

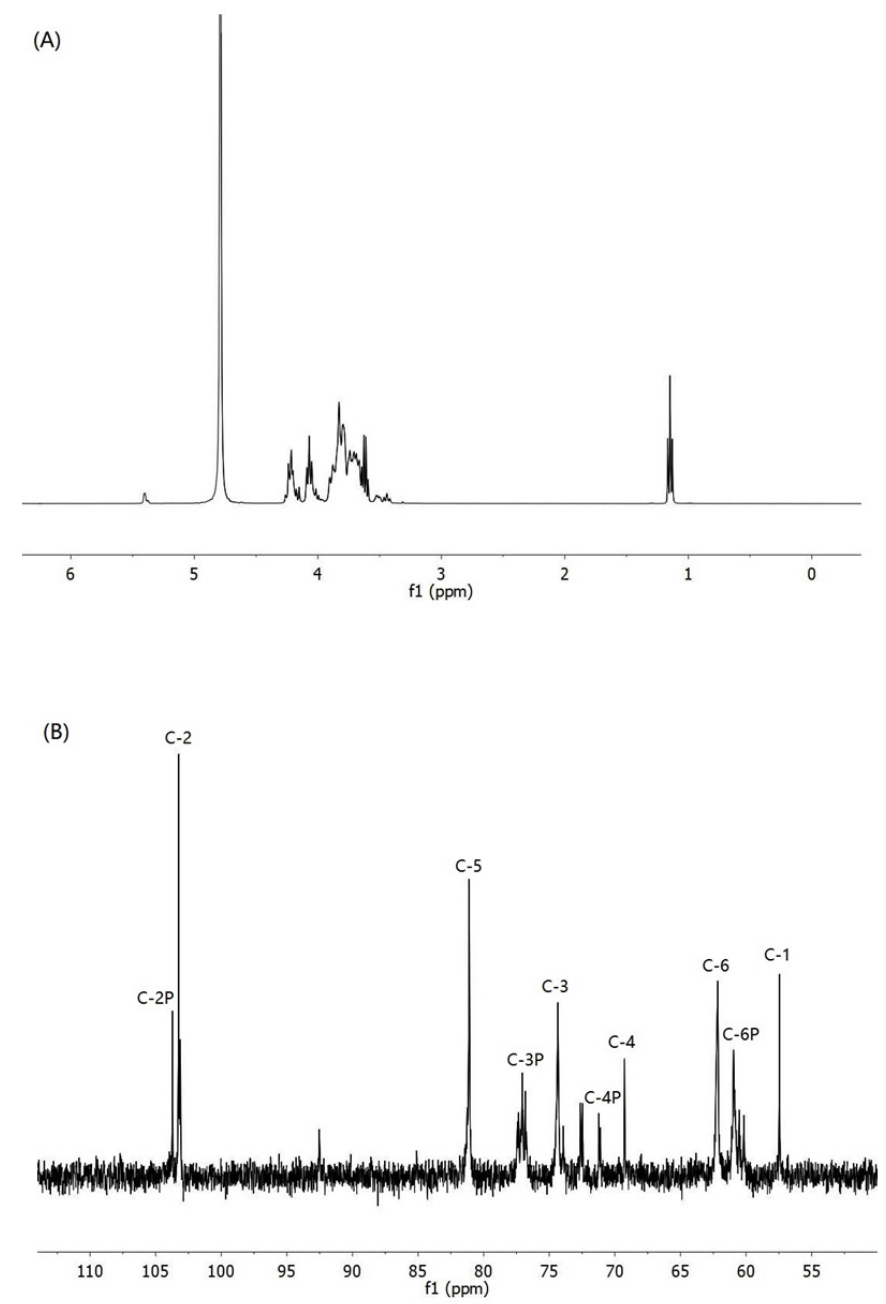

Figure 5. ${ }^{1} \mathrm{H}$ NMR spectra (A) and ${ }^{13} \mathrm{C}$ NMR spectra (B) of the phosphorylated inulin.

were attributed to C-1, C-6, C-4, C-3 and C-5 respectively, of the furanose ring (Anwar et al., 2008; Shiomi, 1993). The spectra of phosphorylated inulin was complex because of the substituents at various positions on the fructose units. There was no free hydroxyl group to react with phosphate group at the C-1, C-2 and C-5 position in furanose ring of inulin. Chemical shift for C-6 moved from $62.16 \mathrm{ppm}$ to $60.95 \mathrm{ppm}$; for C-3 from $74.34 \mathrm{ppm}$ to 77.05 or $72.48 \mathrm{ppm}$; and for C-4 from $69.26 \mathrm{ppm}$ to $71.20 \mathrm{ppm}$ by substitution with phosphate group (Jayakumar et al., 2009; van Hijum et al., 2001). A clear contrast with the phosphorylation reactions of inulin proved the hydroxyl group at the C-6 and C-3 position was selectively substituted prior to the $\mathrm{C}-4$ position. $\mathrm{C}_{6}-\mathrm{OH}$ in the chemical structure of phosphorylated inulin was located in the outside of the sugar ring and its steric hindrance was relatively small and esterification was performed with phosphate easily. The weak peak at $103.72 \mathrm{ppm}$ compared to $103.16 \mathrm{ppm}$ was related to $\mathrm{C}_{2}-\mathrm{OH}$ by substitution in the terminal glucose ring of inulin. These results indicated that the phosphorylation reaction was occurred into inulin.

\subsection{Comparison of prebiotic effects of various carbohydrates}

The growth of intestinal bacteria varied considerably depending on the carbohydrate substrates (Krupa-Kozak et al., 2016; Sims et al., 2014). A decrease in $\mathrm{pH}$ of the culture media, as a result of short chain fatty acid production and an increase in $\log \mathrm{CFU} / \mathrm{g}$ of the plates reflected the ability of the bacteria to grow on the substrates (Bedani et al., 2013; Salazar et al., 2008) (Figure 6). The control culture without the source of carbon showed concentrations of Bifidobacterium animalis at $48 \mathrm{~h}$ of incubation was $7.83 \log \mathrm{CFU} / \mathrm{g}$. After $48 \mathrm{~h}$ incubation, all samples promoted higher increases in levels of Bifidobacteria populations than those occuring in control cultures without carbohydrates added, which was indicative of a stimulatory effect of these substrates on Bifidobacteria. The highest Bifidobacteria concentration of $8.92 \log \mathrm{CFU} / \mathrm{g}$ was due to the glucose being used as carbon source since glucose was a reducing sugar providing antioxidant activity in anaerobic systems. Bifidobacteria concentration of $8.83 \log \mathrm{CFU} / \mathrm{g}$ and $\mathrm{pH} 4.38$ of fermentation liquor were related to inulin as carbon source. CMC (carboxymethylcellulose) could be fermented by Bifidobacterium animalis because the carboxymethyl groups render the CMC (DS $=0.71)$ soluble and biodegradable. The $\mathrm{pH}$ value of fermentation liquor with $10 \mathrm{~g} / \mathrm{L}$ PInu (Phosphorylated inulin, DSp $=0.209$ ) as carbon source was 3.92. PInu carried many negative charges so that bacteria were unable to contact and utilize PInu easily. Negative charges in PInu could be neutralized by calcium. CaPInu could stimulate the growth of Bifidobacteria and decrase $\mathrm{pH}$ in vitro fermentation similar to inulin.

\subsection{Animal experiment}

Initial and final body weight of mice were not affected by CaPInu diet or calcium citrate diet (Table 2). As a result, average daily gain was not different among the treatments. Compared to the control fed the low calcium diet, the serum calcium concentration in mice fed calcium citrate diet was significantly higher $(\mathrm{p}<0.05)$, reaching $99.14 \mathrm{mg} / \mathrm{L}$ whereas the serum phosphate was not higher. CaPInu diet increased the calcium concentration $(\mathrm{p}<0.01)$ and phosphorus concentration $(\mathrm{p}<0.05)$ in the serum compared with the control diet. Serum calcium $\mathrm{x}$ phosphate has been regarded as a risk factor for extraskeletal calcification with the general consensus that it should not exceed $7000 \mathrm{mg}^{2} / \mathrm{L}^{2}$ (Hawley, 2006). A high phosphate $(8 \mathrm{~g} / \mathrm{kg})$ diet was noted to accelerate calcification of the heart, kidney and tongue in healthy DBA/2 mice (van den Broek \& Beynen 1998; Lau et al., 2013). In the present study, the level of phosphate in the CaPInu diet $(4.3 \mathrm{~g} / \mathrm{kg})$ was a safe amount and serum calcium $\mathrm{x}$ phosphate in mice fed CaPInu diet was a relatively modest value $\left(4788.4 \mathrm{mg}^{2} / \mathrm{L}^{2}\right)$ within the appropriate target range. The content of serum calcium in the mice fed the CaPInu diet had no difference compared with the calcium citrate diet. There were no differences in femur length and tibia length among the treatments. Moreover, the femur weight increased $(p<0.05)$ in the groups fed the calcium citrate diet or the CaPInu diet compared to the group fed the control diet. The tibia weight tended to be increased in the groups fed the calcium citrate $\operatorname{diet}(\mathrm{p}=0.07)$ or the CaPInu diet $(\mathrm{p}=0.08)$ compared to the group fed the control diet. There were no differences in femur 
Table 2. Serum and body parameters in mice fed different diets.

\begin{tabular}{|c|c|c|c|}
\hline & Control diet & Calcium citrate diet & CaPInu diet \\
\hline Initial body weight, $g$ & $11.7 \pm 0.8$ & $11.5 \pm 1.0$ & $12.1 \pm 0.9$ \\
\hline Final body weight, $g$ & $37.8 \pm 2.2$ & $37.1 \pm 1.2$ & $38.8 \pm 2.4$ \\
\hline Serum calcium $(\mathrm{mg} / \mathrm{L})$ & $92.81 \pm 4.83^{\mathrm{b}}$ & $99.14 \pm 4.71^{\mathrm{a}}$ & $101.57 \pm 5.26^{\mathrm{a}}$ \\
\hline Serum phosphate $(\mathrm{mg} / \mathrm{L})$ & $43.05 \pm 4.43^{\mathrm{b}}$ & $42.08 \pm 4.67^{\mathrm{b}}$ & $47.13 \pm 3.38^{\mathrm{a}}$ \\
\hline Femur weight, mg & $48.5 \pm 8.9^{\mathrm{b}}$ & $56.2 \pm 6.1^{\mathrm{a}}$ & $57.1 \pm 8.4^{\mathrm{a}}$ \\
\hline Femur length, $\mathrm{mm}$ & $15.5 \pm 0.5$ & $15.8 \pm 0.8$ & $15.7 \pm 0.6$ \\
\hline Tibia weight, mg & $39.1 \pm 6.2$ & $44.2 \pm 5.7$ & $43.7 \pm 5.1$ \\
\hline Tibia length, mm & $18.1 \pm 0.8$ & $17.6 \pm 0.5$ & $18.2 \pm 0.8$ \\
\hline
\end{tabular}

Data were presented as mean $\pm S D(n=10)$; CaPInu = Calcium phosphorylated inulin; $a, b$ - values in rows with different letters differ significantly $(p \leq 0.05)$.

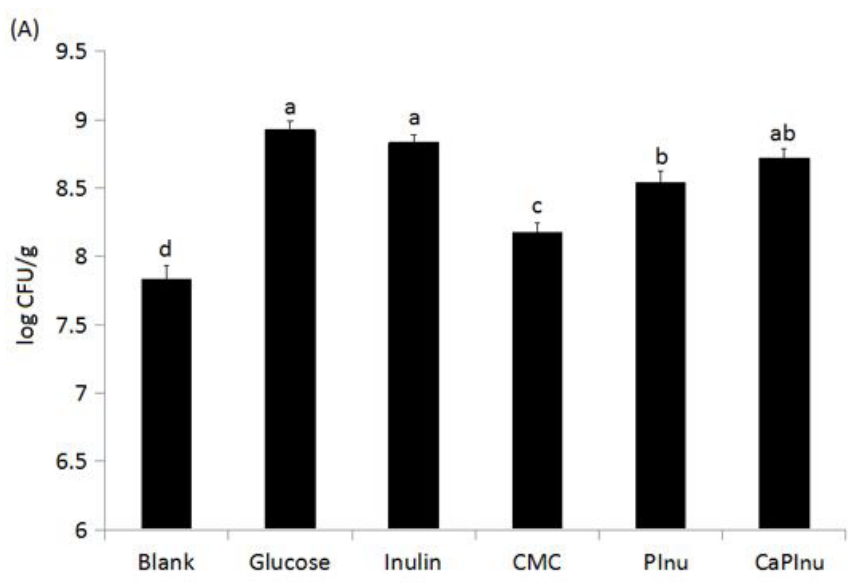

(B)

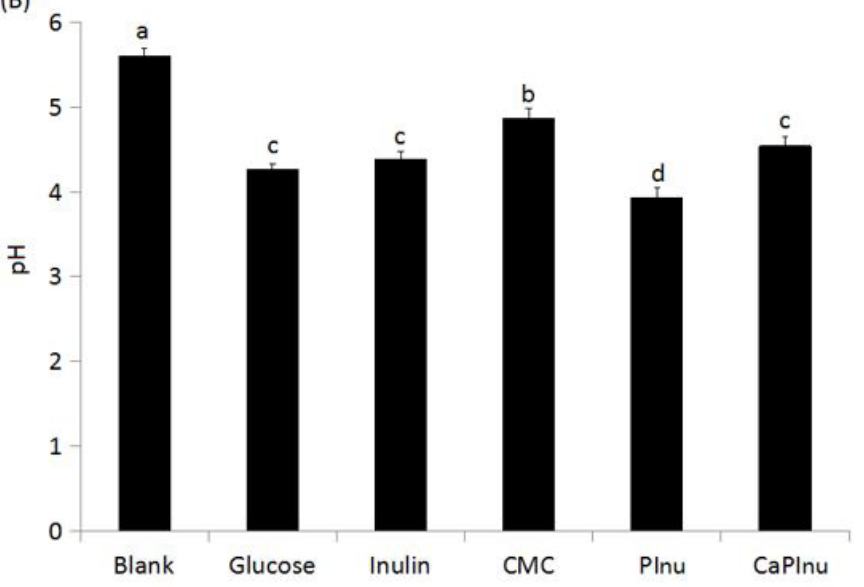

Figure 6. Effects of various carbohydrate substrates, including glucose, inulin, carboxymethylcellulose (CMC), phosphorylated inulin (PInu) and calcium phosphorylated inulin (CaPInu), on log CFU/g (A) and $\mathrm{pH}$ (B) values for Bifidobacterium animalis growth. Each value was expressed as mean $\pm \mathrm{SD}(\mathrm{n}=3)$. Values with different letters were significantly different $(\mathrm{p}<0.05)$.

weight, femur length, tibia weight, tibia length between the mice with calcium citrate diet and CaPInu diet. If there is not enough calcium in the blood, then the body will take calcium from bones, thereby weakening bones. The stimulating effect of CaPInu on the absorption and balance of calcium for growing mice was observed. CaPInu is potential substances that could help to improve the supply with available calcium in human nutrition and by this contribute to bone health. Calcium citrate is a kind of nutrient supplement in food industry. It is speculated that CaPInu has a good effect of calcium supplementation as calcium citrate. It can increase the mineral absorption and will be used in the treatment of calcium deficiency.

\section{Conclusions}

This study proposes to use a phosphorylated derivative of inulin as a potential functional food that contributes to enhance the bioavailability of calcium in the colon, propitiated by lactic acid production and after fermentation by Bifidobacteria. This work opens new perspectives by taking advantage of the introduction of phosphonic groups into inulin, providing the chelating ability of calcium ions for phosphorylated inulin. CaPInu had positive effects on intestinal microflora. Calcium plays a very important role in the body. Compared to controls fed the low Calcium diet, mice fed the CaPInu diet had a higher serum calcium $(\mathrm{p}<0.01)$ and femur weight $(\mathrm{p}<0.05)$. Study findings will aid future investigations in ascertaining the factors related to potential bone health benefits of CaPInu which will aid in developing an effective prebiotics food supplement. Additional work is needed to examine potentia of the ability of CaPInu to increase bone formation rates.

\section{References}

Abou-Arab, A. A., Talaat, H. A., \& Abu-Salem, F. M. (2011). Physicochemical properties of inulin produced from Jerusalem Artichoke tubers on bench and pilot plant scale. Australian Journal of Basic and Applied Sciences, 5(5), 1297-1309.

Abrams, S. A., Griffin, I. J., Hawthorne, K. M., Liang, L., Gunn, S. K., Darlington, G., \& Ellis, K. J. (2005). A combination of prebiotic short- and long-chain inulin-type fructans enhances calcium absorption and bone mineralization in young adolescents. The American Journal of Clinical Nutrition, 82(2), 471-476. http://dx.doi. org/10.1093/ajcn/82.2.471. PMid:16087995.

Anwar, M. A., Kralj, S., van der Maarel, M. J., \& Dijkhuizen, L. (2008). The probiotic Lactobacillus johnsonii NCC 533 produces highmolecular-mass inulin from sucrose by using an inulosucrase enzyme. Applied and Environmental Microbiology, 74(11), 3426-3433. http:// dx.doi.org/10.1128/AEM.00377-08. PMid:18408060.

Bedani, R., Rossi, E. A., \& Isay Saad, S. (2013). Impact of inulin and okara on Lactobacillus acidophilus La-5 and Bifidobacterium animalis Bb-12 viability in a fermented soy product and probiotic survival under in 
vitro simulated gastrointestinal conditions. Food Microbiology, 34(2), 382-389. http://dx.doi.org/10.1016/j.fm.2013.01.012. PMid:23541206.

Bogden, J. D., Kemp, F. W., Huang, A. E., Shapses, S. A., Ambia-Sobhan, H., Jagpal, S., Brown, I. L., \& Birkett, A. M. (2008). Bone mineral density and content during weight cycling in female rats: effects of dietary amylase-resistant starch. Nutrition \& Metabolism, 5(1), 34. http://dx.doi.org/10.1186/1743-7075-5-34. PMid:19036159.

Broulík, P. D., \& Broulíková, K. (2007). Raloxifen prevents bone loss in castrated male mice. Physiological Research, 56(4), 443-447. PMid:16925465.

Butts, C. A., Paturi, G., Tavendale, M. H., Hedderley, D., Stoklosinski, H. M., Herath, T. D., Rosendale, D., Roy, N. C., Monroad, J. A., \& Ansellad, J. (2016). The fate of ${ }^{13} \mathrm{C}$-labelled and non-labelled inulin predisposed to large bowel fermentation in rats. Food \& Function, 7(4), 1825-1832. http://dx.doi.org/10.1039/C5FO01056J. PMid:26778667.

Coudray, C., Feillet-Coudray, C., Tressol, J. C., Gueux, E., Thien, S., Jaffrelo, L., Mazur, A., \& Rayssiguier, Y. (2005). Stimulatory effect of inulin on intestinal absorption of calcium and magnesium in rats is modulated by dietary calcium intakes short- and long-term balance studies. European Journal of Nutrition, 44(5), 293-302. http://dx.doi. org/10.1007/s00394-004-0526-7. PMid:15340751.

Dendougui, F., \& Schwedt, G. (2004). In vitro analysis of binding capacities of calcium phytic acid in different food samples. European Food Research and Technology, 219(4), 409-415. http://dx.doi. org/10.1007/s00217-004-0912-7.

Dewulf, E. M., Cani, P. D., Claus, S. P., Fuentes, S., Puylaert, P. G. B., Neyrinck, A. M., Bindels, L. B., de Vos, W. M., Gibson, G. R., Thissen, J. P., \& Delzenne, N. M. (2013). Insight into the prebiotic concept: lessons from an exploratory, double blind intervention study with inulin-type fructans in obese women. Gut, 62(8), 1112-1121. http:// dx.doi.org/10.1136/gutjnl-2012-303304. PMid:23135760.

García, P., Vergara, C., \& Robert, P. (2015). Release kinetic in yogurt from gallic acid microparticles with chemically modified inulin. Journal of Food Science, 80(10), C2147-C2152. http://dx.doi. org/10.1111/1750-3841.13001. PMid:26305430.

Griffin, I. J., Hicks, P. M., Heaney, R. P., \& Abrams, S. A. (2003). Enriched chicory inulin increases calcium absorption mainly in girls with lower calcium absorption. Nutrition Research (New York, N.Y.), 23(7), 901-909. http://dx.doi.org/10.1016/S0271-5317(03)00085-X.

Grube, M. (2002). Infrared spectra of some fructans. Spectroscopy (Springfield, Or.), 16, 289-296. http://dx.doi.org/10.1155/2002/637587.

Hartzell, A. L., Maldonado-Gómez, M. X., Hutkins, R. W., \& Rose, D. J. (2013a). Synthesis and in vitro digestion and fermentationof acylated inulin. Bioactive Carbohydrates and Dietary Fibre, 1(1), 81-88. http://dx.doi.org/10.1016/j.bcdf.2013.01.004.

Hartzell, A. L., Maldonado-Gómez, M. X., Yang, J., Hutkins, R. W., \& Rose, D. J. (2013b). In vitro digestion and fermentation of 5-formylaminosalicylate-inulin: A potential prodrug of 5-aminosalicylic acid. Bioactive Carbohydrates and Dietary Fibre, 2(1), 8-14. http:// dx.doi.org/10.1016/j.bcdf.2013.08.001.

Hawley, C. (2006). Calcium $\times$ phosphate product. Nephrology (Carlton, Vic.), 11, S206-S208. http://dx.doi.org/10.1111/j.1440-1797.2006.00645.x.

James, L. (2014). Effect of inulin on the growth and antimicrobial activity of Bifidobacterium animalis Subsp. Lactis 420 - an assessment. World Applied Sciences Journal, 32, 553-559. http://dx.doi.org/10.5829/ idosi.wasj.2014.32.04.84314.

Jayakumar, R., Egawa, T., Furuike, T., Nair, S. V., Tamura, H., \& Tandon, P. (2009). Synthesis, characterization, and thermal properties of phosphorylated chitin for biomedical applications. Polymer Engineering and Science, 49(5), 844-849. http://dx.doi.org/10.1002/pen.21306.
Jayakumar, R., Nagahama, H., Furuike, T., \& Tamura, H. (2008). Synthesis of phosphorylated chitosan by novel method and its characterization. International Journal of Biological Macromolecules, 42(4), 335-339. http://dx.doi.org/10.1016/j.ijbiomac.2007.12.011. PMid:18279950.

Jedrzejczak-Krzepkowska, M., Tkaczuk, K. L., \& Bielecki, S. (2011). Biosynthesis, purification and characterization of $\beta$-fructofuranosidase from Bifidobacterium longum KN29.1. Process Biochemistry, 46(10), 1963-1972. http://dx.doi.org/10.1016/j.procbio.2011.07.005.

Krupa-Kozak, U., Świątecka, D., Bączek, N., \& Brzóska, M. M. (2016). Inulin and fructooligosaccharide affect in vitro calcium uptake and absorption from calcium-enriched gluten-free bread. Food \& Function, 7(4), 1950-1958. http://dx.doi.org/10.1039/C6FO00140H. PMid:26965706.

Lau, W. L., Linnes, M., Chu, E. Y., Foster, B. L., Bartley, B. A., Somerman, M. J., \& Giachelli, C. M. (2013). High phosphate feeding promotes mineral and bone abnormalities in mice with chronic kidney disease. Nephrology, Dialysis, Transplantation, 28(1), 62-69. http://dx.doi. org/10.1093/ndt/gfs333. PMid:23045434.

Legette, L. L., Lee, W., Martin, B. R., Story, J. A., Campbell, J. K., \& Weaver, C. M. (2012). Prebiotics enhance magnesium absorption and inulin-based fibers exert chronic effects on calcium utilization in a postmenopausal rodent model. Journal of Food Science, 77(4), 88-94. http://dx.doi.org/10.1111/j.1750-3841.2011.02612.x. PMid:22394255.

Lingyun, W., Jianhua, W., Xiaodong, Z., Da, T., Yalin, Y., Chenggang, C., Tianhua, F., \& Fan, Z. (2007). Studies on the extracting technical conditions of inulin from Jerusalem artichoke tubers. Journal of Food Engineering, 79(3), 1087-1093. http://dx.doi.org/10.1016/j. jfoodeng.2006.03.028.

Mandracchia, D., Tripodo, G., Latrofa, A., \& Dorati, R. (2014). Amphiphilic inulin-D- $\alpha$-tocopherol succinate (INVITE) bioconjugates for biomedical applications. Carbohydrate Polymers, 103, 46-54. http://dx.doi.org/10.1016/j.carbpol.2013.11.056. PMid:24528699.

Miremadi, F., \& Shah, N. P. (2012). Applications of inulin and probiotics in health and nutrition. International Food Research Journal, 19, 1337-1350.

Morros, J., Levecke, B., \& Infante, M. R. (2011). Hydrophobically modified inulin from alkenyl succinic anhydride in aqueous media. Carbohydrate Polymers, 84(3), 1110-1116. http://dx.doi.org/10.1016/j. carbpol.2010.12.077.

Nishi, N., Ebina, A., Nishimura, S., Tsutsumi, A., Hasegawa, O., \& Tokura, S. (1986). Highly phosphorylated derivatives of chitin, partially deacetylated chitin and chitosan as new functional polymers - preparation and characterization. International Journal of Biological Macromolecules, 8(5), 311-317. http://dx.doi.org/10.1016/01418130(86)90046-2.

Nishi, N., Maekita, Y., Nishimura, S., Hasegawa, O., \& Tokura, S. (1987). Highly phosphorylated derivatives of chitin, partially deacetylated chitin and chitosan as new functional polymers: metal binding property of the insolubilized materials. International Journal of Biological Macromolecules, 9(2), 109-114. http://dx.doi. org/10.1016/0141-8130(87)90035-3.

Noguchi, Y., Homma, I., \& Matsubara, Y. (2017). Complete nanofibrillation of cellulose prepared by phosphorylation. Cellulose (London, England), 24(3), 1295-1305. http://dx.doi.org/10.1007/s10570-017-1191-3.

Palumbo, A. V., Zhang, C., Liu, S., Scarborough, S. P., Pfiffner, S. M., \& Phelps, T. J. (1996). Influence of media on measurement of bacterial populations in the subsurface. Applied Biochemistry and Biotechnology, 57(1), 905-914. http://dx.doi.org/10.1007/BF02941771.

Passauer, L., Bender, H., \& Fischer, S. (2010). Synthesis and characterisation of starch phosphates. Carbohydrate Polymers, 82(3), 809-814. http:// dx.doi.org/10.1016/j.carbpol.2010.05.050. 
Roberfroid, M. B. (2007). Inulin-type fructans: functional food ingredients. The Journal of Nutrition, 137(11, Suppl), 2493S-2502S. http://dx.doi. org/10.1093/jn/137.11.2493S. PMid:17951492.

Sahiner, N., \& Sagbas, S. (2014). Multifunctional tunable p(inulin) microgels. Materials Science and Engineering C, 40, 366-372. http:// dx.doi.org/10.1016/j.msec.2014.04.028. PMid:24857504.

Salazar, N., Gueimonde, M., Hernández-Barranco, A. M., Ruas-Madiedo, P., \& de los Reyes-Gavilán, C. G. (2008). Exopolysaccharides produced by intestinal Bifidobacterium strains act as fermentable substrates for human intestinal bacteria. Applied and Environmental Microbiology, 74(15), 4737-4745. http://dx.doi.org/10.1128/AEM.00325-08. PMid:18539803.

Scholz-Ahrens, K. E., Acil, Y., \& Schrezenmeir, J. (2002). Effect of oligofructose or dietary calcium on repeated calcium and phosphorus balances, bone mineralization and trabecular structure in ovariectomized rats. British Journal of Nutrition, 88(4), 365-377. http://dx.doi.org/10.1079/BJN2002661. PMid:12323086.

Shiomi, N. (1993). Structure of fructopolysaccharide (asparagosin) from roots of asparagus (Asparagus officinalis L.). The New Phytologist, 123(2), 263-270. http://dx.doi.org/10.1111/j.1469-8137.1993.tb03734.x.

Shnawa, H. A. (2011). Evaluation of lignin-calcium complex as thermal stabilizer for poly vinyl chloride. Materials Sciences and Applications, 2(06), 692-699. http://dx.doi.org/10.4236/msa.2011.26095.

Sims, I. M., Ryan, J. L., \& Kim, S. H. (2014). In vitro fermentation of prebiotic oligosaccharides by Bifidobacterium lactis HN019 and Lactobacillus spp. Anaerobe, 25, 11-17. http://dx.doi.org/10.1016/j. anaerobe.2013.11.001. PMid:24239979.

Sitohy, M. Z., El-Saadany, S. S., Labib, S. M., \& Ramadan, M. F. (2000). Physicochemical properties of different types of starch phosphate monoesters. Starch, 52(4), 101-105. http://dx.doi.org/10.1002/1521379X(200006)52:4<101::AID-STAR101>3.0.CO;2-W.
Slavin, J. (2013). Fiber and prebiotics: mechanisms and health benefits. Nutrients, 5(4), 1417-1435. http://dx.doi.org/10.3390/nu5041417. PMid:23609775.

van den Broek, F. A. R., \& Beynen, A. C. (1998). The influence of dietary phosphorus and magnesium concentrations on the calcium content of heart and kidneys of DBA/2 and NMRI mice. Laboratory Animals, 32(4), 483-491. http://dx.doi.org/10.1258/002367798780599758. PMid:9807763.

van Hijum, S. A. F. T., Bonting, K., van der Maarel, M. J. E. C., \& Dijkhuizen, L. (2001). Purification of a novel fructosyltransferase from Lactobacillus reuteri strain 121 and characterization of the levan produced. FEMS Microbiology Letters, 205(2), 323-328. http://dx.doi. org/10.1016/S0378-1097(01)00490-6. PMid:11750822.

Verraest, D. L., Peters, J. A., Batelaan, J. G., \& van Bekkum, H. (1995). Carboxymethylation of inulin. Carbohydrate Research, 271(1), 101-112. http://dx.doi.org/10.1016/0008-6215(95)00028-R. PMid:7648576.

Weaver, C. M., Martin, B. R., Ebner, J. S., \& Krueger, C. A. (1987). Oxalic acid decreases calcium absorption in rats. The Journal of Nutrition, 117(11), 1903-1906. http://dx.doi.org/10.1093/jn/117.11.1903. PMid:3681480.

Wongsagonsup, R., Shobsngob, S., Oonkhanond, B., \& Varavinit, S. (2005). Zeta potential $(\zeta)$ and pasting properties of phosphorylated or cross-linked rice starches. Starch, 57(1), 32-37. http://dx.doi. org/10.1002/star.200400311.

Wu, X. Y., \& Lee, P. I. (2000). Preparation and characterization of inulin ester microspheres as drug carriers. Journal of Applied Polymer Science, 77(4), 833-840. http://dx.doi.org/10.1002/(SICI)10974628(20000725)77:4<833::AID-APP17>3.0.CO;2-4.

Yu, Y., Jin, X., \& Fu, J. (2006). Test method for Ca ion chelating power and comparison thereof. Text Auxiliaries, 23, 39-42. http://dx.doi. org/10.3969/j.issn.1004-0439.2006.12.012. 